\title{
MODELING OF HYBRID PHOTOVOLTAIC THERMAL WATER PUMPING SYSTEM
}

\author{
Esraa Tayseer ${ }^{1}$, Mohamed Rady ${ }^{2,3}$, Ahmed.A.Ali ${ }^{4}$, R. R. Darwish ${ }^{3}$ \\ ${ }^{1}$ Department of Mechatronics Engineering, High Institute of Engineering, Giza, Egypt \\ ${ }^{2}$ Department of Mechanical Engineering, King Abdulaziz University, KSA \\ ${ }^{3}$ Department of Mechanical Engineering, Helwan University, Cairo, Egypt \\ ${ }^{4}$ Department of Electrical Power and Machines engineering, Faculty of Engineering, Helwan \\ University, Cairo, Egypt \\ Received :29 Nov. $2021 \quad$ Accepted:19 Dec. 2021
}

\begin{abstract}
This paper presents the design and performance evaluation of the hybrid photovoltaic thermal water pumping system (PVTWPS). The photovoltaic panel generates the electricity needed to supply the water pump. A flat-plate sheet and tubes absorber is attached at the bottom of the PV panel. The water that flows through the absorber cools the PV panel. The proposed configuration aims to increase the efficiency of a low-power standalone PVTWPS and produce hot water. A detailed model has been built for each component using the Matlab platform. To operate the proposed system at maximum power point (MPP), a fuzzy logic controller (FLC) and a modified perturb and observe approach $(\mathrm{P} \& \mathrm{O})$ were used. The electrical and thermal performance of a PVT water collector was determined under various levels of irradiance. At each irradiance level, various mass flow rates were introduced. Electrical, thermal, and overall efficiencies were assessed. The simulation results show that the proposed system is effective and efficient.
\end{abstract}

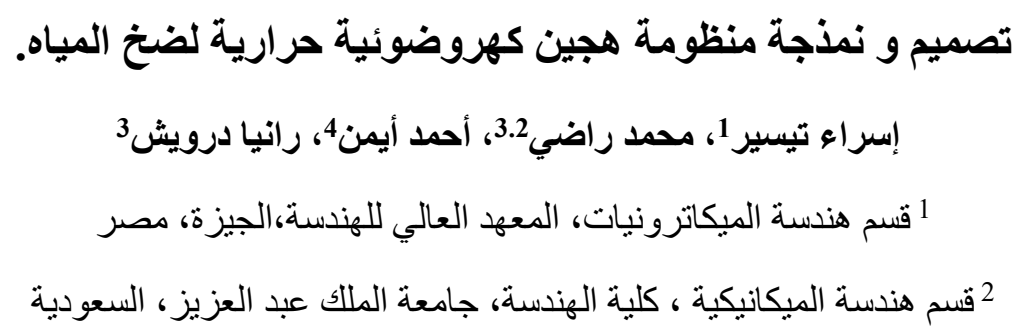




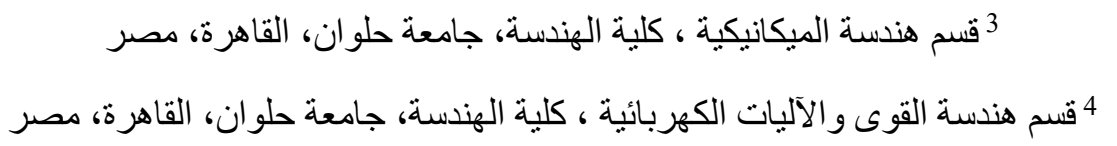

الملخص:

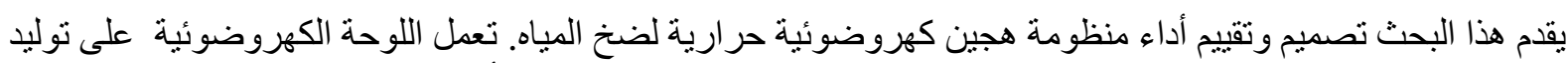

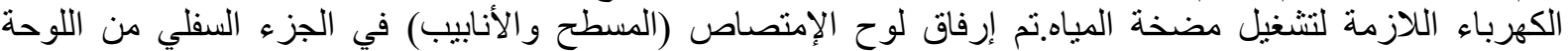

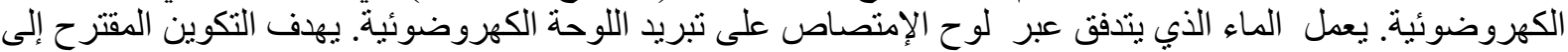

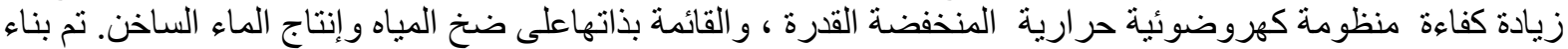

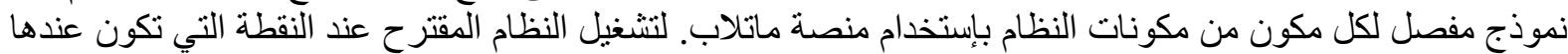

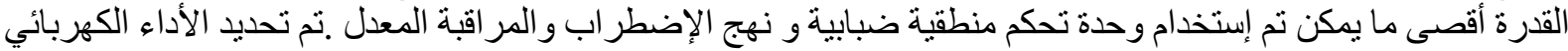

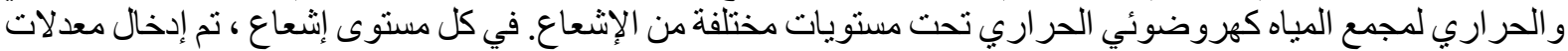

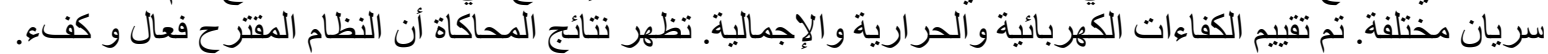

\section{INTRODUCTION}

Advances in electronics and digital control have contributed to the increased focus on renewable energy as a more environmentally friendly and price efficacious generation source. It is gaining importance as it addresses climate change, high fuel prices, energy deficiencies, and limited fossil fuel sources worldwide. Solar energy has stood out as one of the most convenient alternatives to conventional energy, commonly passed through transportation and distribution lines due to its abundance near the load center. The sun's energy can be harnessed in various other ways, including solar warming, photovoltaic, solar thermal energy, etc. [1]. PV devices (solar cells) have several features as a source. PV devices require no repair once installed, has no movable parts, and converts energy cleanly and directly. The conversion efficiency of a PV system, on the other hand, varies between 10 and $20 \%$ depending on factors such as type, module temperature, irradiance, a spectrum of sunlight, dirt, shading, and varying loads [2].

The solar radiation, absorbed but not converted into electricity, raises the module's temperature and reduces its electrical efficiency. As a result, heat extraction is required to maintain a satisfactory level of electrical efficiency, which can be achieved by using either water or air heat recovery [3]. For this purpose, PVT technology is developed. It is a technology that integrates photovoltaic and solar thermal collectors into a single module to improve solar conversion efficiency and utilize the space efficiently [4]. It can produce both power and heat simultaneously, allowing it to take advantage of both Solar panels and solar thermal collectors.

Kern and Russell [5] presented the first PVT module design in 1978. Florschuetz constructed a theoretical and experimental model for the PVT module performance with a solar collector model in 1979[6]. Fudholi tested three water flow paths: web-flow, straight flow, and spiral flow for a photovoltaic thermal collector. The best performance resulted from the spiral absorber [7]. Al-Shamani [8] also tested PVT modules using a variety of nanoparticles (SiC, $\mathrm{SiO} 2$, and $\mathrm{TiO} 2$ ). The fluid, including $\mathrm{SiC}$, showed the best performance, according to the results. Yu [9] developed an unglazed PVT with a thermo-laminating bonding method for attaching the absorber plate. The electrical and thermal efficiency improved as a result. Two passes and vertical fins in the PVT lower air path were designed by Kumar et al. [50]. They observed that large-area fins could reduce cell temperature from $88^{\circ} \mathrm{C}$ to $66^{\circ} \mathrm{C}$. Cooling PVT modules with phase change material were investigated numerically (Kazemian [11], Fayaz [12], Gaur [13], AL-Musawi [14], and in an experimental investigation, the thermal efficiency was $72 \%$ Al-Waeli et al., [15]. The electrical combination's efficiency was enhanced from $1.7 \%$ to 
$13 \%$ Hossain et al. [16].In addition, A PVT collector was also used in a household for integrated cooling, warming, and electricity production (Ramos[17], Herrando[18], where the PVT collector output supplied $60 \%$ of the heat requirement and $100 \%$ of the cooling need.

Based on the nonlinear I-V characteristics and efficiency decline of the PV system under operating conditions, an MPPT was required. The MPPT control ensures that maximum electricity produced is delivered to the loads [19]. The various MPPT strategies are proposed to obtain an optimal duty cycle to the converter so that the operating point can be relocated to the maximum power point. Traditional approaches or intelligent algorithms can be used to track the MPP. Traditional techniques include the incremental conductance, perturb and observe, Hill Climbing, ripple correlation control, fractional open-circuit voltage, and fractional short-circuit current method. The incremental conductance, perturb and observe algorithms in PV systems are the most commonly used [20]. These techniques apply a fixed step to identify the optimum duty cycle value, which may result in incorrect or slow results when temperature or solar irradiation changes unexpectedly and suddenly. Artificial intelligence techniques such as neural networks, fuzzy logic, and neuro fuzzy[21]. These techniques apply a variable step to identify the optimum duty cycle value resulting in a faster response and more constancy under all conditions. The performance of different MPPT strategies were compared [22].

Irrigation pumps and rural water supply is the essential application for standalone PV systems [23]. Many novel schemes for improving photovoltaic pumping performance have been reported in the literature. PVPS design procedure for system sizing, installation, mounting, and monitoring is reviewed in [24]. Katan et al. [25] investigated the performance of PVPS that included a PV array, permanent magnet motor, sun tracker, and helical rotor pump. They reported that applying an MPPT and a sun-tracker improved the system's performance. A solar PVPS is developed using a buck converter to boost the current to the DC pump [26].To reduce costs and maintenance, the system does not use a battery or an inverter. In addition, the economic and environmental study indicated that photovoltaic pumping systems are feasible compared to standard diesel-powered systems [27]. Applications of PVT collector included solar cooling consume $7 \%$ of total energy, solar thermal technologies, such as solar air heating and tap water heating, $39 \%$ and $45 \%$, respectively, industrial heating $6 \%$, drying 3\%, and pool heating $0.2 \%[6][28]$.

The current study aims to design and evaluate the performance of a hybrid PVT water pumping system. The proposed plan meets the electricity needs for water pumping and produces hot water used for residential applications. A flat-plate sheet and tube collector using water as a coolant is designed to be installed at the bottom of PV panels. Proper design of the PVT hybrid system would increase the overall solar conversion efficiency. The performance of the hybrid PVT system depends on the solar irradiance, operating temperature, inlet water temperature, and water mass flow rate. To evaluate the system performance, a detailed system model was built in the Matlab Simulink environment. A fuzzy logic controller (FLC) is employed to operate the proposed system at maximum power point (MPP). The results of an FLC are compared with a modified perturb and observe (P\&O) MPPT algorithm under constant radiation and abruptly fluctuate. The performance of a hybrid PVT sy292stem is evaluated in terms of the electrical efficiency of PV panels, thermal efficiency of collectors, and overall PVT efficiency.

The paper is arranged as illustrated below. Section 2 presents the details of the proposed system. Modeling and simulation of the PVTWPS are presented in section 3. Maximum Power Point 
Tracking is discussed in section 4. Results and discussion are illustrated in section 5. The final section includes the conclusion.

\section{THE PROPOSED SYSTEM}

The proposed system is standalone PVTWPS without backup batteries, as shown in Fig.1. It consists of PV modules with flat plate sheet and tube collector, dc water pump, control valve, and MPPT to track MPP, including a boost converter and MPPT algorithm. The flow of water from the pump is diverted in two paths. One path is going directly for water pumping into the water storage tank of irrigation. The other part passes through a regulating valve to the thermal collector beneath the PV panel for panel cooling. The hot water exit from the PV panel is stored in a hot water tank for domestic utilization. The hot water storage tank can also be used in many other applications that require thermal energy, such as crops drying.

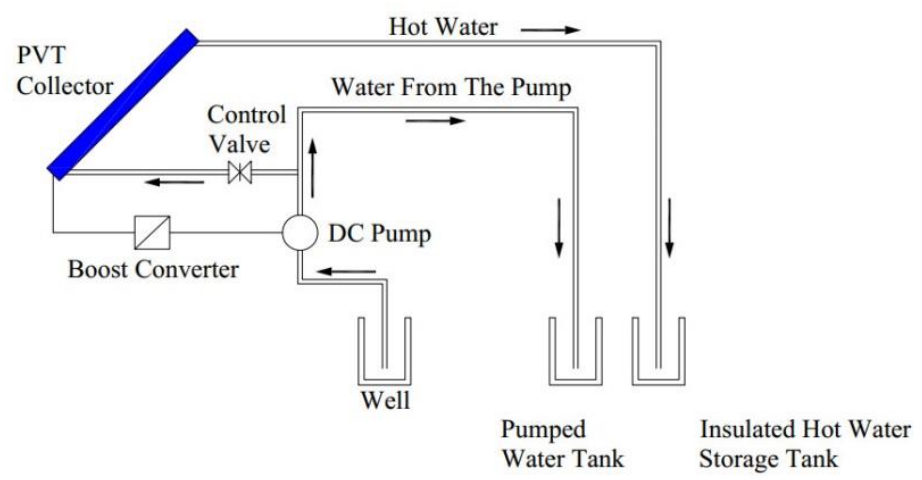

Fig. 1: The proposed standalone PVTWPS.

\section{MODELLING AND SIMULATION OF THE PVTWPS}

\subsection{Electrical Model For PVT Collector}

Photovoltaic converts sunlight into electricity by using semiconductor materials. Because a typical PV cell generates less than 2 watts at approximately 0.5 volts, the cells must be connected to the module in a parallel series arrangement to deliver sufficient power. A PV array is a collection of several PV modules electrically wired in series and parallel sequence to provide sufficient required power to match the desired load [29]. As many researchers have reported, solar radiation, temperature, and load current affect the generated current [30,31, 32 ]. Fig. 2 illustrates a PV cell equivalent circuit.

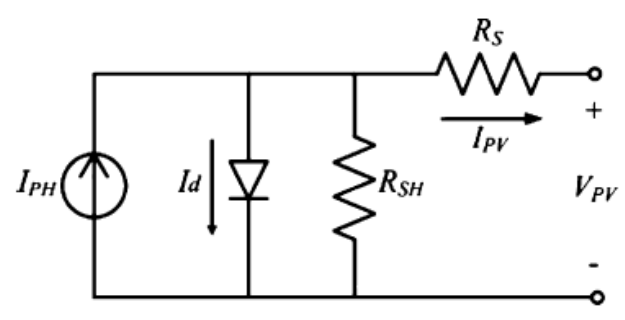

Fig.2: Solar cell equivalent electrical circuit[29].

Using Kerchief's current law as a basis, the solar cell's output current is calculated as follows:

$$
\mathrm{I}_{\mathrm{PV}}=\mathrm{I}_{\mathrm{PH}}-\mathrm{I}_{\mathrm{d}}-\mathrm{I}_{\mathrm{SH}}
$$




$$
\begin{aligned}
& \mathrm{I}_{\mathrm{PV}}=\mathrm{I}_{\mathrm{PH}}-\mathrm{I}_{\mathrm{S}}\left[\exp \left(\frac{\mathrm{q}\left(\mathrm{V}_{\mathrm{PV}}+\mathrm{I}_{\mathrm{PV}} \mathrm{R}_{\mathrm{s}}\right.}{\mathrm{KT}_{\mathrm{C}} \mathrm{A}}\right)-1\right]-\frac{\mathrm{V}_{\mathrm{PV}}+\mathrm{I}_{\mathrm{PV}} \mathrm{R}_{\mathrm{s}}}{\mathrm{R}_{\mathrm{SH}}} \\
& \mathrm{I}_{\mathrm{pH}}=\left[\mathrm{I}_{\mathrm{sc}}+\mathrm{K}_{\mathrm{I}}\left(\mathrm{T}_{\mathrm{c}}-\mathrm{T}_{\mathrm{REF}}\right)\right] \lambda
\end{aligned}
$$

$\mathrm{V}_{\mathrm{PV}}$ is the output voltage of the solar cell, $\mathrm{I}_{\mathrm{PH}}$ is the light generated current, $\mathrm{I}_{\mathrm{S}}$ is the diode saturation current, A ideality factor of the diode (from 1 to 2 ), $\mathrm{q}$ is the electron charge $1.6 \times 10^{-19} \mathrm{C}, \mathrm{K}$ is the Boltzmann constant $\left(1.38 \times 10^{-23} \mathrm{~J} / \mathrm{K}\right), \mathrm{T}_{\mathrm{C}}$ is the actual cell temperature $\left({ }^{\circ} \mathrm{C}\right.$ ), $\mathrm{T}_{\mathrm{REF}}$ is the reference temperature (usually $25^{\circ} \mathrm{C}$ ), $\mathrm{K}_{\mathrm{I}}$ is the temperature coefficient, ISC is the short circuit current, $\lambda$ irradiation on a surface $\left(\mathrm{W} / \mathrm{m}^{2}\right) /$ nominal irradiation $\left(1000 \mathrm{~W} / \mathrm{m}^{2}\right)$. The last term in equation (2) becomes relatively small compared to the other terms [29] because the shunt resistance $\mathrm{R}_{\mathrm{SH}}$ is much greater than the series resistance $R_{S}$. As a result, the last term will be discarded because it will not make a significant error in the PV cell model. The PV module IS4000P 300 was selected to drive PMDC Motor [33,34].

Table 1. represents the parameters of the module.

Table 1: Electrical parameters of the IS4000P $300 \mathrm{PV}$ module.

\begin{tabular}{lc}
\hline Electrical parameters & Value \\
\hline Maximum power $\left(\mathrm{P}_{\max }\right)$ & $300 \mathrm{~W}$ \\
Voltage at maximum power point $\left(\mathrm{V}_{\mathrm{mmp}}\right)$ & $37.6 \mathrm{~V}$ \\
current at maximum power point $\left(\mathrm{V}_{\mathrm{mmp}}\right)$ & $7.98 \mathrm{~A}$ \\
Open circuit voltage $\left(\mathrm{V}_{\mathrm{oc}}\right)$ & $45 \mathrm{~V}$ \\
Short circuit current $\left(\mathrm{I}_{\mathrm{sc}}\right)$ & $8.54 \mathrm{~A}$ \\
Temperature coefficient of $\mathrm{I}_{\mathrm{sc}}$ & $0.06 \% /{ }^{\circ} \mathrm{C}$ \\
Temperature coefficient of $\mathrm{V}_{\mathrm{oc}}$ & $-0.31 \% /{ }^{\circ} \mathrm{C}$ \\
\hline
\end{tabular}

\subsection{Thermal Model For PVT Collector}

More electricity is generated when a PV module is cooled. The heat rejected from PV can be used for many applications. The PVT collector has commercial appeal due to its integral characteristics and decreases space and cost per unit of useful power generation. A onedimensional steady-state model for PVT collector was developed to analyze the thermal and electrical performance [7, 8]. A detailed arrangement of a front view of a flat plate sheet and tubes PVT collector is shown in Fig. 3. The various parts include the glass cover, photovoltaic module, absorber plate connected to the bottom of the panel via a layer of adhesive, and a metallic bond connecting the tubes to the absorber plate [35].

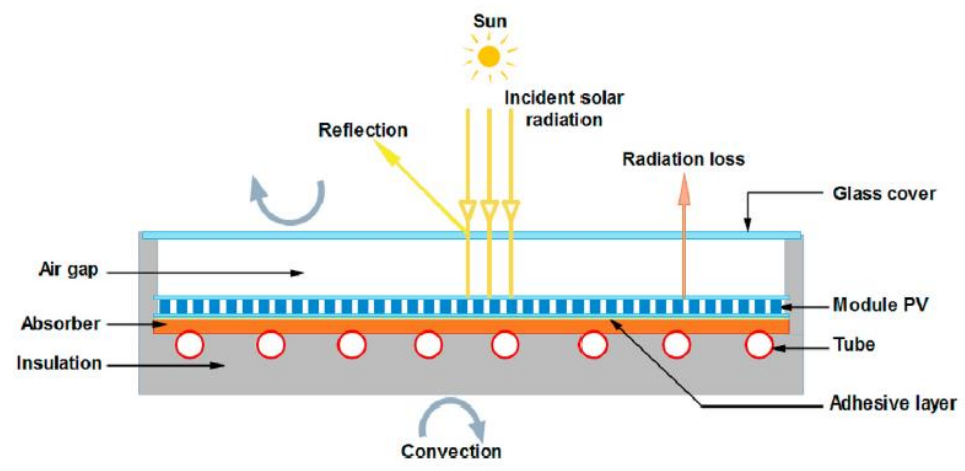

Fig. 3: A front sectional view of a sheet and tubes PVT collector [35].

The following assumptions are used to facilitate mathematical models of the thermal energy balance of a water PVT collector: 
- Constant thermophysical properties.

- Wind speed is uniformly distributed around the collector.

- Uniform water flow.

- Only the top of the PVT collector loses heat; the back and edge are well insulated.

- No partial shading or dust.

- Quasi-steady system.

Eq. (4) can be used to determine the useful heat gain under these conditions

$$
\mathrm{Q}_{\mathrm{u}}=\dot{\mathrm{m}} \mathrm{C}_{\mathrm{p}}\left(\mathrm{T}_{\mathrm{o}}-\mathrm{T}_{\mathrm{i}}\right)
$$

Where $\dot{m}$ is the mass flow rate, $C_{p}$ is the heat capacity of water, $T_{o}, T_{i}$ is the water temperature at the inlet and exit of the collector, respectively. $Q_{u}$ can also be written in terms of the difference of absorbed irradiance, generated electrical energy, and heat loss [36]:

$$
Q_{u}=A_{c}\left[G_{T}(\tau \alpha)_{P V}-U_{l}\left(T_{p m}-T_{a}\right)-\mathrm{Q}_{\mathrm{e}}\right]
$$

Where $A_{c}$ is the collector area, $T_{a}$ is the ambient temperature. $U_{l}$ is the collector heat loss coefficient, $Q_{e}$ is the electrical power produced from the module, and $\tau \alpha$ is the photovoltaic module's transmittance absorptance product. $T_{p m}$ is the mean absorber plate temperature. Since $T_{p m}$ is affected by many factors, including different collector designs, working medium properties, and solar irradiance, it is hard to measure or calculate [36]. To simplify the analysis, Hottel and Whillier [37] adjust the formulae for a flat plate collector by substituting the mean absorber temperature by the inlet temperature, which has been frequently utilized in designing and assessment of liquid and air solar collectors.

$$
\mathrm{Q}_{\mathrm{u}}=\mathrm{A}_{\mathrm{c}} \mathrm{F}_{\mathrm{R}}\left[\mathrm{G}_{\mathrm{T}}(\tau \alpha)_{\mathrm{PV}}-\mathrm{U}_{\mathrm{l}}\left(\mathrm{T}_{\mathrm{i}}-\mathrm{T}_{\mathrm{a}}\right)-\mathrm{Q}_{\mathrm{e}}\right]
$$

$F_{R}$ is the heat removal efficiency factor, which is defined as follows:

$$
F_{R}=\frac{\dot{m} C_{p}}{A_{c} U_{l}}\left[1-\exp \left(-\frac{A_{c} U_{l} \grave{F}}{\dot{m} C_{p}}\right)\right]
$$

Where $\mathrm{F}$ is the collector efficiency factor which is defined as follows:

$$
\grave{F}=\left[\frac{\frac{1}{U_{l}}}{U_{l}(D+(W-D) F)}\right]+\frac{1}{C_{b}}+\frac{1}{2(a+b) h_{f i}}
$$

$\mathrm{W}$ is the distance between tubes, $\mathrm{D}$ is the tube diameter, $C_{b}$ is The bond conductance, $h_{f i}$ is the heat transfer coefficient of the fluid, and $\mathrm{F}$ is the efficiency factor, which is defined as follows:

$$
F=\frac{\tanh \left(M \frac{W-D}{2}\right)}{\sqrt{M \frac{W-D}{2}}}
$$


Where $\mathrm{M}$ is the thermal conductivity of the absorber and the PV cell, which is defined as follows [38]:

$$
M=\sqrt{\frac{U_{l}}{k_{a b s} l_{a b s}+k_{P V} l_{P V}}}
$$

Where $l_{p v}$ is the PV panel thickness, $K_{p v}$ is the PV thermal conductivity, $l_{a b s}$ is the absorber thickness, $K_{a b s}$ is the absorber thermal conductivity, and $U_{l}$ is the overall loss coefficient is defined as follows[6]:

$$
U_{l}=U_{e}+U_{t}+U_{b}
$$

$U_{e}$ is the edge loss coefficient, $U_{b}$ is the Loss coefficient of the bottom, and $U_{t}$ is the top loss coefficient is calculated as follows:

$$
U_{t}=\left\{\frac{N}{\frac{C}{T_{p m}}\left[\frac{T_{p m}-T_{a}}{(N+f)}\right]^{e}} \frac{1}{h_{w}}\right\}^{-1}+\frac{\sigma\left(T_{p m}+T_{a}\right)\left(T_{p m}{ }^{2}+T_{a}{ }^{2}\right)}{\left(\varepsilon_{p}+0.00591 N h_{w}\right)^{-1}+\frac{2 N+f-1+0.133 \varepsilon_{p}}{\varepsilon_{g}}-N}
$$

Where

$$
\begin{aligned}
& C=520\left(1-0.000051 \beta^{2}\right) \\
& f=\left(1+0.089 h_{w}-0.1166 h_{w} \varepsilon_{p}\right)(1+0.07866 N) \\
& e=0.43\left(1-\frac{100}{T_{p m}}\right) \\
& \quad Q / A_{c} \\
& T_{p m}=T_{i}+\frac{A_{R} U_{l}}{F_{R}}\left(1-F_{R}\right) \\
& h_{w}=2.8+3.0 v
\end{aligned}
$$

$\varepsilon_{p}$ is the plate emittance, $\sigma$ is the Stefan Boltzmann constant, $N$ is the number of covers, $\beta$ is the collector mounting, $\varepsilon_{g}$ is the glass emittance, $T_{p m}$ the mean plate temperature and $h_{w}$ is the wind heat transfer coefficient [39]. The PVT collector characteristics are listed in Table 2. The simulation model of the PVT collector is shown in Fig. 4. Thermal efficiency of the PVT collector $\left(\eta_{t h}\right)$ is a ratio of the useful thermal energy $Q_{u}$, to the overall incoming solar radiation $G$, and can be written as:

$$
\eta_{\mathrm{th}}=\frac{\mathrm{Q}_{\mathrm{u}}}{\mathrm{GA}}
$$

The electrical efficiency $\left(\eta_{\mathrm{PV}}\right)$ of the PVT collector is calculated by the following relations: 
$\eta_{P V}=\frac{V_{m} I_{m}}{G A}$

Where $I_{m}$ is the maximum current and $V_{m}$ is the maximum voltage. The overall PVT efficiency was used to assess the system's overall performance and is written as follows [36]:

$\eta_{P V T}=\eta_{t h}+\eta_{P V}$

Table 2: Design parameters for the flat plate water PVT collector used in this work $[6,7,38,42]$.

\begin{tabular}{cccc}
\hline Description & Symbol & Value & Unit \\
\hline Collector area & $\mathrm{Ac}$ & 1.8 & $\mathrm{~m}^{2}$ \\
Number of glass cover & $\mathrm{N}$ & 1 & - \\
Emittance of glass & $\varepsilon_{g}$ & 0.88 & - \\
Emittance of plate & $\varepsilon_{p}$ & 0.95 & - \\
Collector tilt & $\beta$ & 30 & - \\
Transmittance & $\tau$ & 0.88 & - \\
Absorbance & $\alpha$ & 0.95 & - \\
Heat transfer inside tube & $h_{f i}$ & 333 & $\mathrm{~W} / \mathrm{m}{ }^{\circ} \mathrm{C}$ \\
Specific heat of working fluid & $C_{p}$ & 4180 & $\mathrm{~J} / \mathrm{kg}{ }^{\circ} \mathrm{C}$ \\
PV panel thickness & $l_{p V}$ & 0.005 & $\mathrm{~m}$ \\
PV thermal conductivity & $k_{p V}$ & 130 & $\mathrm{~W} / \mathrm{m} 2{ }^{\circ} \mathrm{C}$ \\
Absorber conductivity & $k_{a b s}$ & 401 & $\mathrm{~W} / \mathrm{m} 2{ }^{\circ} \mathrm{C}$ \\
Absorber thickness & $l_{a b s}$ & 0.001 & $\mathrm{~m}$ \\
Fin thickness & $\sigma$ & 0.0005 & $\mathrm{~m}$ \\
Fluid mass flow rate & $\dot{m}$ & $0.015-0.045$ & $\mathrm{~kg} / \mathrm{s}$ \\
Diameter of collector & $\mathrm{D}$ & 0.0127 & $\mathrm{~m}$ \\
Tube spacing & $\mathrm{W}$ & 0.042 & $\mathrm{~m}$ \\
\hline
\end{tabular}

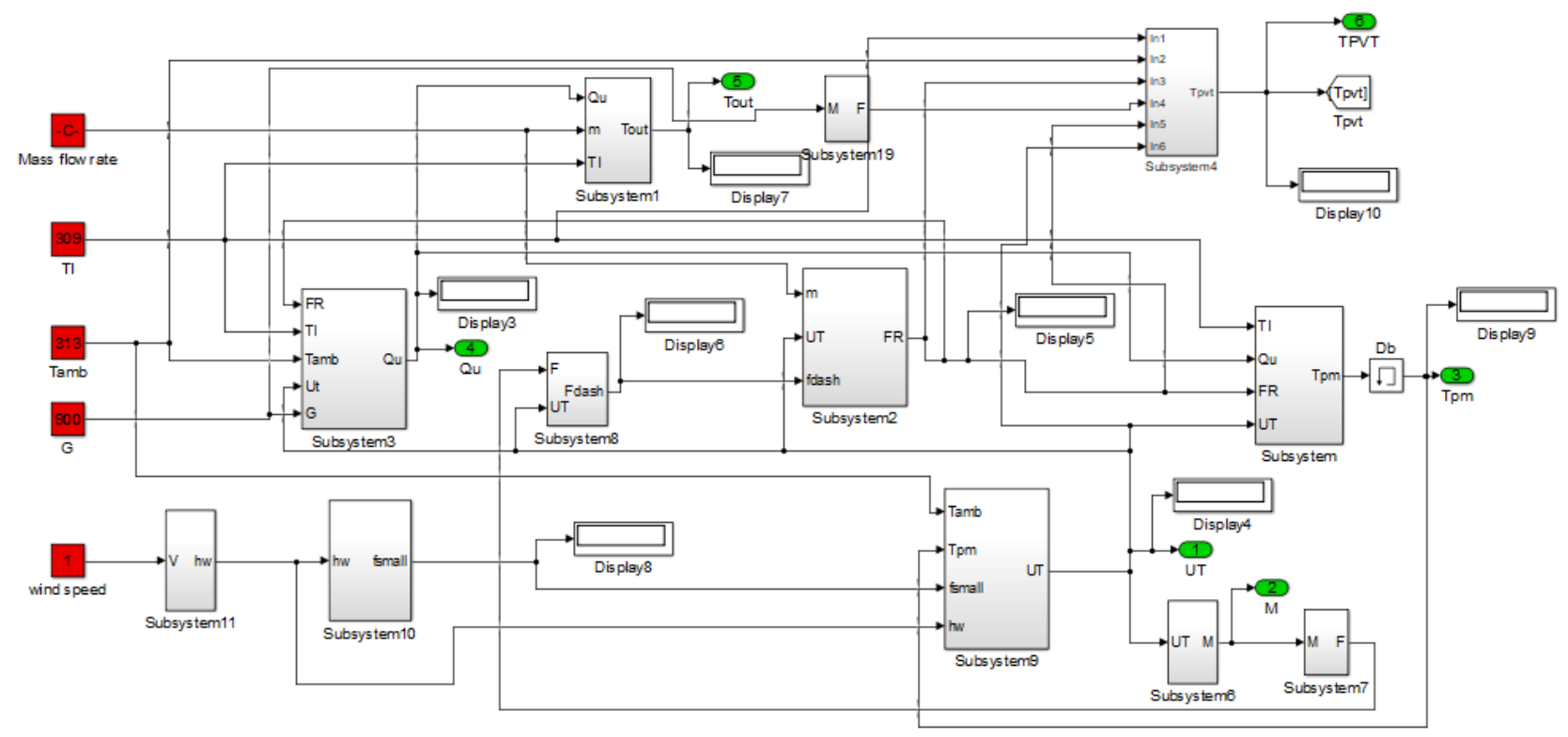

Fig. 4: MATLAB Simulink model of the PVT collector. 


\subsubsection{NOCT And The Temperature Of PVT Collector}

The electrical energy produced by the PVT or PV panels can be calculated when the panel temperature and radiation are known. Several mathematical models, steady-state and dynamic, have been introduced to evaluate the panel temperature. The latest models for determining the temperature of the photovoltaic thermal collector are listed in [40]. Although, the evaluation stays difficult due to a lot of info on heat transfer characteristics and thermal properties that are needed. As a result, the assessment is taking a long time, and the methodology is not practical. Ross [41] proposed different methods to compute the temperature of a PV panel by evaluating the nominal operating cell temperature NOCT.

The NOCT is the temperature of the module with a radiation $800 \mathrm{~W} / \mathrm{m}^{2}$ and a temperature of $20^{\circ} \mathrm{C}$. The manufacturer usually provides the NOCT values, and the PV panel temperature can be approximated. Ross' correlation outcomes are in very good agreement with the experimental data [43]. This strategy is more effective and practical than the others. The following is the formula for calculating cell temperature:

$$
T_{p v}=T_{a}+\frac{G}{800}(N O C T-20)
$$

Manufacturers frequently include the NOCT in the datasheet for the module, which is about $45^{\circ} \mathrm{C}$ for monocrystalline and polycrystalline. The temperature of a PVT collector is expressed by applying the energy balance.

The solar radiation captured by the PV panel is transformed into thermal energy in the circulating water and heat loss under no electrical load. As a result, the thermal energy balance for the PVT collector is addressed, and the NOCT of the PVT collector is represented as follows [40]:

$$
N O C T=800 F_{R} \frac{T_{i}-T_{a}}{G}+\frac{\tau \alpha}{U_{l}}\left(1-F_{R}\right) 800+20
$$

\subsubsection{MODEL VALIDATION}

A theoretical model was prepared for a water-type PVT collector using Matlab/Simulink platform. Validations for the present study were performed using the previously published data of A. Fudholi et al. (2014) [7], as shown in Fig.5.The Indoor experimental model of A. Fudholi et al. (2014) consists of three absorber designs inserted below the PV panel. The absorber types include web-flow, spiral-flow, and direct-flow. In the present study one-dimensional model is developed, and one geometry is designed to transfer the heat from PV. The absorber is a direct flow circular tube and sheet. The electrical and thermal performances of a PVT collector were investigated. The results show the effectiveness of the simulation model. 


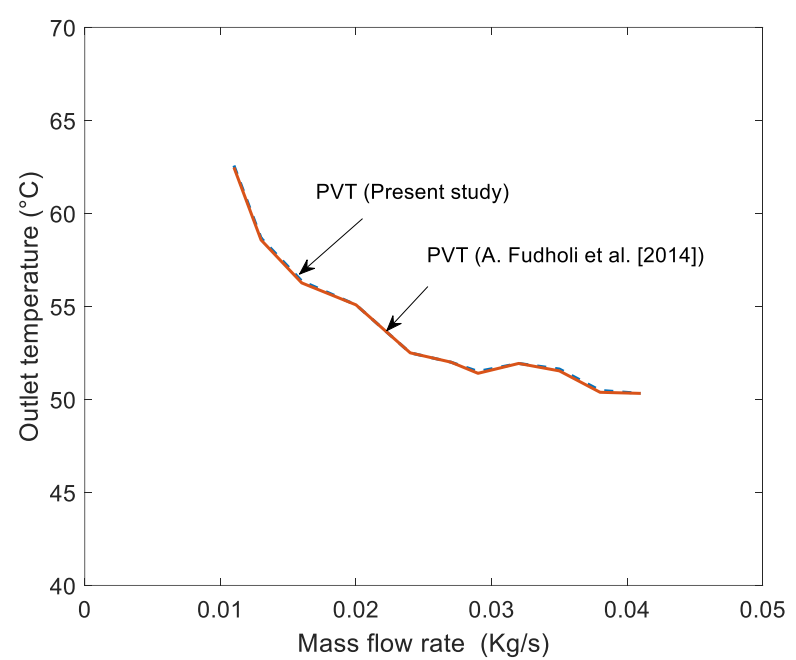

Fig.5: Comparison of the output temperature of the current study with the previously published data [ 7 ].

\subsection{BOOST CONVERTER}

The boost converter is one of the simplest power electronic circuits to step up the DC voltage from the PV panel to the desired level. The basic boost converter circuit is represented in Fig.6. It comprises an inductor, a power electronic switch (typically a MOSFET or an IGBT), and a diode. It may have a filter capacitor to smooth the output [43].

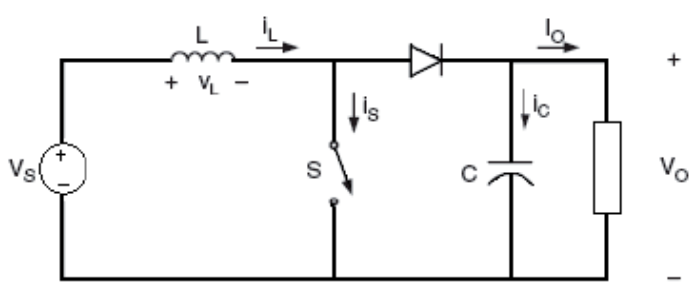

Fig.6: The boost converter circuit diagram[43].

Assuming there are no losses in the power circuit, we have output power $P_{\text {out }}=$ input power $P_{\text {in }}$. Because output voltage $V_{\text {out }}>$ input voltage $V_{\text {in }}$, the input current $I_{\text {in }}>$ the output current $I_{\text {out }}$. Switching to a boost converter is achieved by using IGBT as a switch. The energy supplied is stored in the inductor as magnetic energy when the switch is closed or conducts current. As a result, the inductor current increases. When the switch is opened, the current passes through the inductor, starts to drop, and is released through the diode and the load. The relation between duty cycle $D$ and output voltage $V_{\text {out }}$ is given by Eq. (22).

$$
\begin{aligned}
& V_{\text {OUT }}=\frac{V_{I N}}{1-D} \\
& I_{O U T}=I_{I N}(1-D) \\
& R_{I N}=R_{\text {OUT }}(1-D)^{2}
\end{aligned}
$$


It is evident from Eq. (23) and (24) that the MPP tracking algorithm can change the value of $R_{\text {in }}$ by adjusting duty $D$. The converter operates at MPP when $R_{\text {in }}=R_{\text {optimal }}$, and hence maximum power is transferred to the load [44]. The designed parameters for the boost converter are represented in Table 3.

Table 3: Designed parameters for the boost converter.

\begin{tabular}{cc}
\hline Electrical parameters & Value \\
\hline Capacitance (C) & $2200 \mu F$ \\
Inductance (L) & $5 \mathrm{mH}$ \\
Frequency & $3 \mathrm{kHz}$ \\
\hline
\end{tabular}

\subsection{MOTOR PUMP SET}

The solar PV pumping system is a frequently utilized application in rural areas to assure water supply for communities without access to the grid. There is widespread agreement that DC motors in general, and PM DC motors in particular, are more efficient and effective in PV applications. As a result, PM DC motors are an appropriate candidate for PV pump systems. Positive displacement (PD) and centrifugal pumps are the most popular pumps utilized in PVPS. The PD pump is the best and most appropriate option for subterranean water pumping applications, as this type of pump performs well in higher head applications [25]. This paper will combine the PM DC motor with the PD pump to achieve a more efficient, simple, and lowcost PVPS. The PMDC motor's mathematical model is as follows:

$$
\begin{aligned}
& V_{a}=R_{a} I_{a}+L \frac{d I_{a}}{d t}+K_{e} \omega \\
& T_{e}=K_{e} I_{a} \\
& J \frac{\mathrm{d} \omega}{d t}=T_{e}-T_{p}-B \omega
\end{aligned}
$$

Where $\omega$ is the motor speed ( $\mathrm{rad} / \mathrm{sec}), R_{a}$ is the armature resistance $(\Omega), V_{a}$ is the motor voltage, and $I_{a}$ is the armature current (A). $J$ is the moment of inertia, $K_{e}$ is the voltage constant (V.sec/rad), $K_{t}$ is the torque constant (N. m/A), $B$ is a viscous torque constant, and $T_{e}$ is the electromagnetic torque. $T_{d}$ is The load (pump) torque (N.m), which is constant for the PD pump [2]. The equivalent circuit of the permanent magnet de motor is shown in Fig.7. The motor parameters are listed in Table 4. [34].

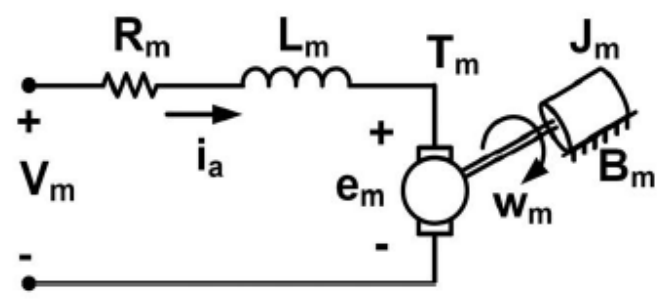

Fig.7: Equivalent circuit of the PMDC motor[23]. 
Table 4: The PMDC motor parameters.

\begin{tabular}{lc}
\hline Motor parameters & Value \\
\hline Armature resistance & $7.72 \Omega$ \\
Armature inductance & $0.16273 \mathrm{H}$ \\
Back e.m.f constant & $1.25 \mathrm{~V} / \mathrm{rad} / \mathrm{s}$ \\
Mechanical inertia & $0.0236 \mathrm{Kg} \cdot \mathrm{m} 2$ \\
Friction coefficient & $0.003 \mathrm{~N} . \mathrm{m} / \mathrm{rad} / \mathrm{s}$ \\
Rated armature current & $2.7 \mathrm{~A}$ \\
Speed & $1500 \mathrm{rev} / \mathrm{min}$ \\
\hline
\end{tabular}

\section{MAXIMUM POWER POINT TRACKING}

MPPT is a link between the load and PV generator, enabling the system to follow the MPP. The converter and the MPPT algorithm are the main components of the MPPT. In this paper, both FLC and a modified $P \& O$ approach are utilized to calculate the optimal duty cycle $D$ of the converter; thus controlling the equivalent input resistance, $R_{I N}$ at terminals of the module adjust it to optimal value $R_{\text {optimal }}$, hence compensating for the MPP error e and ensures perfect tracking of the maximum available power. The proposed PVTWPS is simulated under three different cases. Figure 10 presents the direct-coupled system without MPPT. Figure 11 introduces the system with a modified P\&O algorithm, and Fig.12 presents the system with FLC.

\subsection{MPPT Using A Modified P\&O}

A modified perturb and observe $(P \& O)$ approach is generally used by a large number of authors. It is simple and only requires measuring the voltage $\left(\mathrm{V}_{\mathrm{pv}}\right)$ and current $\left(\mathrm{I}_{\mathrm{pv}}\right)$ of the PV panel, respectively, and It can also locate the maximum PowerPoint. While the temperature and radiation fluctuate, the algorithm of the $P \& O$ is represented in the flowchart Fig.8. Vpv (k) and $\mathrm{Ipv}(\mathrm{k})$ are measured at each cycle to calculate $\operatorname{Ppv}(\mathrm{k})$ and $\operatorname{Ppv}(\mathrm{k}-1)$ value calculated in the previous cycle by Vpv $(\mathrm{k}-1)$ and Ipv $(\mathrm{k}-1)$ The operating voltage $(\mathrm{Vpv})$ is increased (perturbed) by a small decrease ( $\mathrm{dD}$ ) in the duty cycle of the boost converter and observing the change in power divided by the change in current $(\mathrm{dP} / \mathrm{dI})$. When $(\mathrm{dP} / \mathrm{dI})<0$, the system is moving towards the $M P P$, the perturbation of the operating voltage point should be in the same direction by decreasing the duty cycle. At $(\mathrm{dP} / \mathrm{dI})=0$ the system is operating at $M P P$ and for $(\mathrm{dP} / \mathrm{dI})>0$ the system is moving away from the MPP. the perturbation of the operating voltage point should be in the opposite direction by decreasing the duty cycle [45]. 


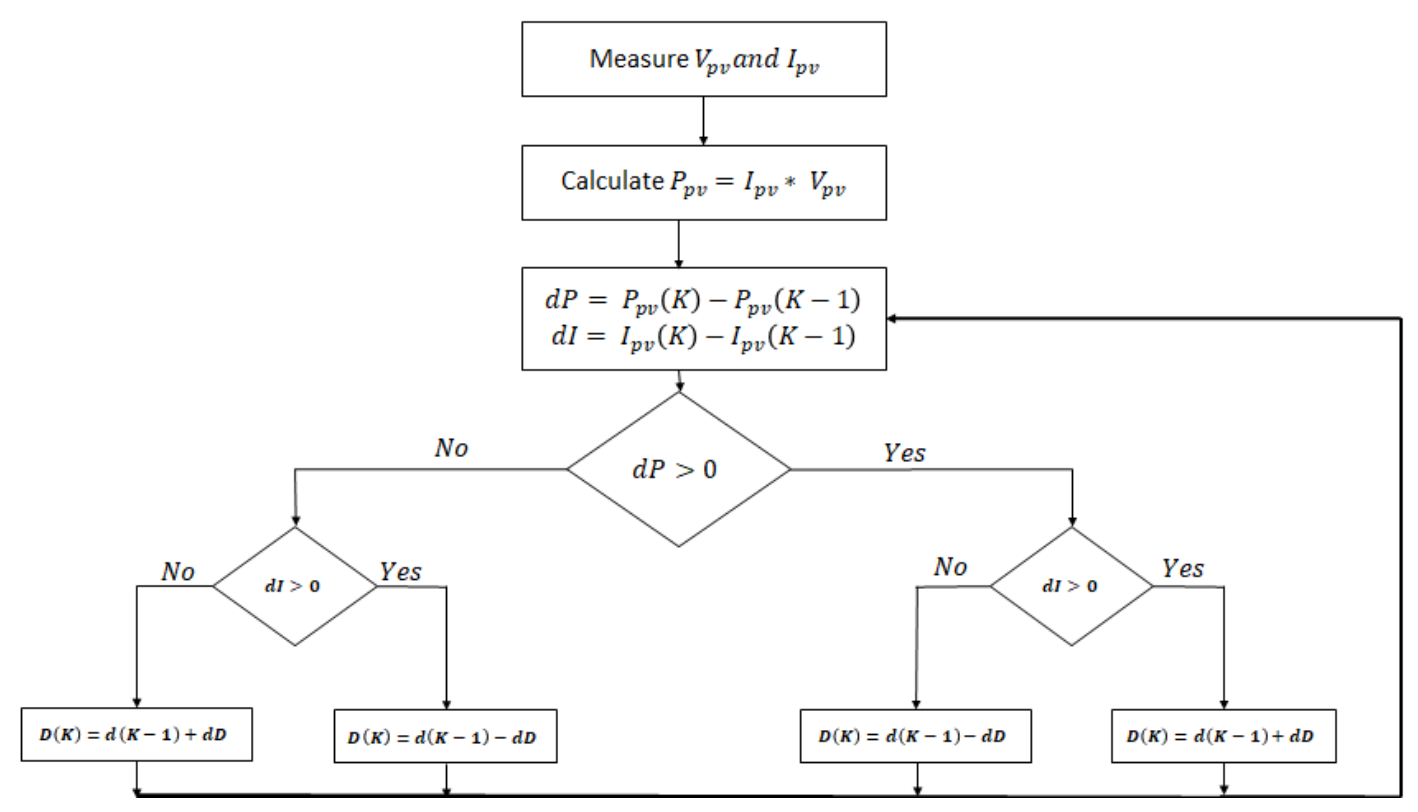

Fig.8: A modified P\&O algorithm.

\subsection{MPPT Using FLC}

Loftih A. Zadeh, a computer science professor at the University of California, Berkeley, was the first one to introduce fuzzy logic theory. Mamdani, on the other hand, implemented the first practical fuzzy logic controller in 1974.

Fuzzy logic mimics the way humans think. It is based on linguistic variables with IF-THEN rules. A fuzzy logic controller is divided into a fuzzification block, a rule-based inference system, and a defuzzification block. The fuzzification block converts crisp input values to linguistic values, and the inference system determines the output linguistic variables based on the crisp values. The defuzzification block transforms the linguistic variables into crisp values [21,34].

The input variables of FLC are $d P$ and $d I$

$$
\begin{aligned}
& d P=P_{p v}(K)-P_{p v}(K-1) \\
& d I=I_{p v}(K)-I_{p v}(K-1)
\end{aligned}
$$

The output variable is $d D$

$$
d D=D(K)-D(K-1)
$$

Where $d P$ is the change in PV power, $d I$ is the change in PV current, and $d D$ is the change in the duty cycle of the boost converter. Fig.9 shows the memberships function of input and output fuzzy sets [19]. Each fuzzy set has four membership functions as follows \{PB (Positive Big), PS (Positive Small), NS (Negative Small), and NB (Negative Big)\}. The fuzzy system rules can be designed as shown in Table 3[33]. 

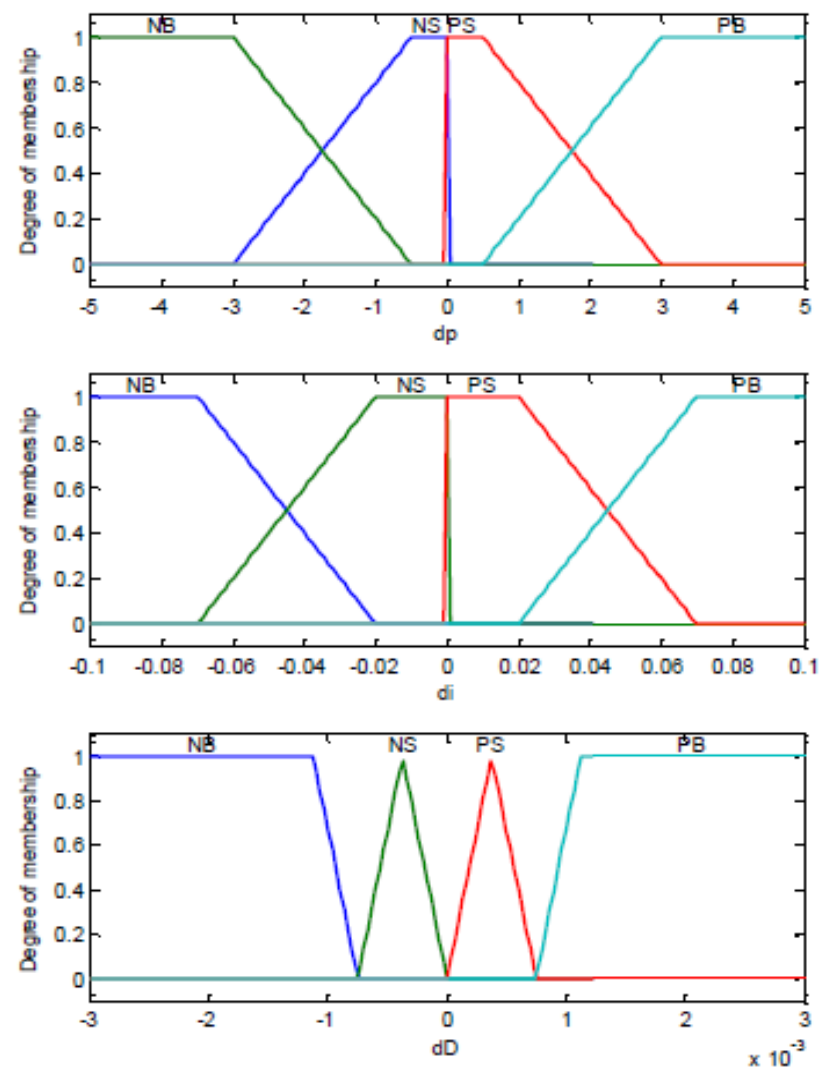

Fig. 9: Membership functions of fuzzy system.

\begin{tabular}{|c|c|c|c|c|}
\hline $\mathrm{dI}$ & PB & PS & NS & NB \\
\hline PB & PB & PB & NB & NB \\
\hline PS & PS & PS & NS & NS \\
\hline NS & NS & NS & PS & PS \\
\hline NB & NB & NB & PB & PB \\
\hline
\end{tabular}

Table 5: Fuzzy rules table.

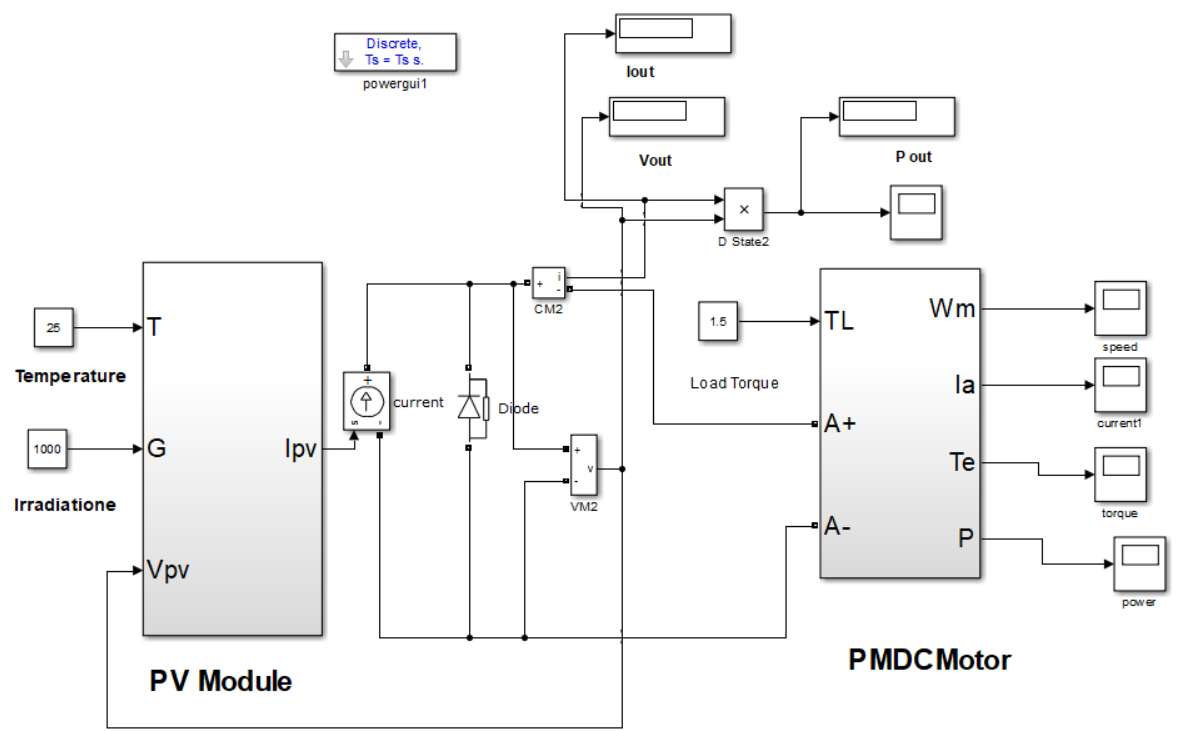

Fig.10: A simulation model of the PV module direct coupled to PMDC Motor. 


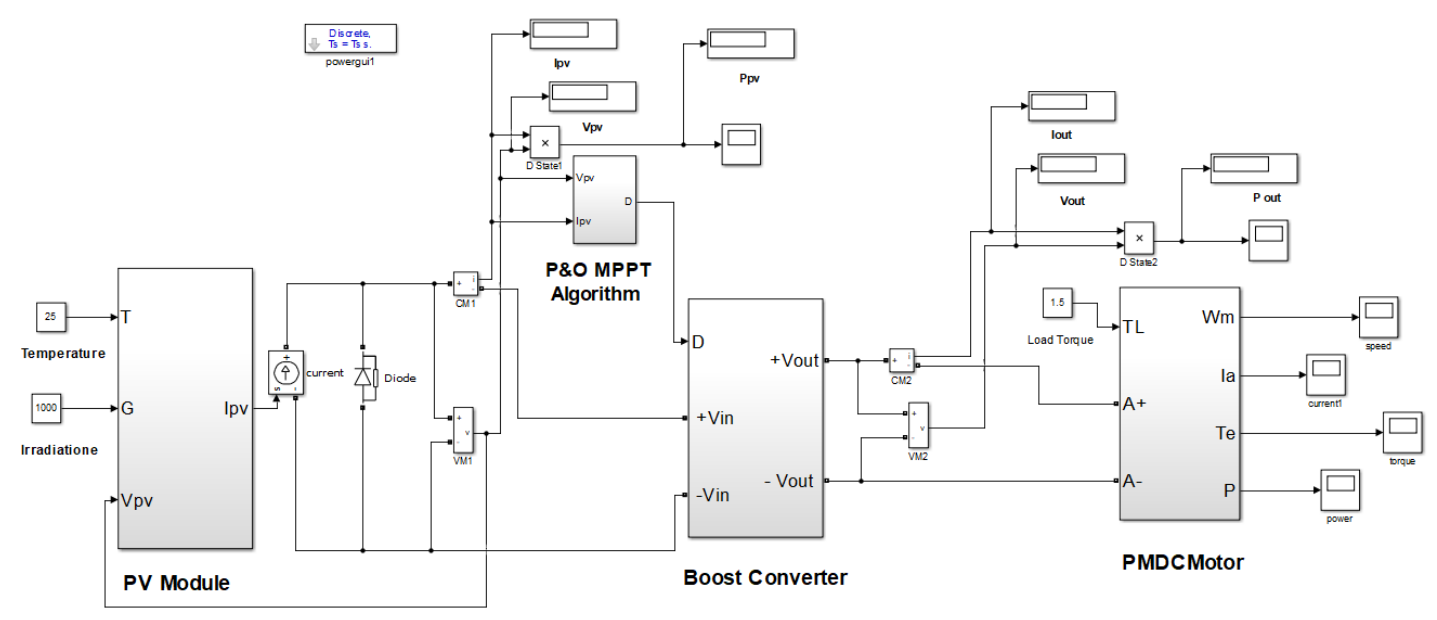

Fig. 11: A simulation model of the PV system with a modified $P \& O$ algorithm

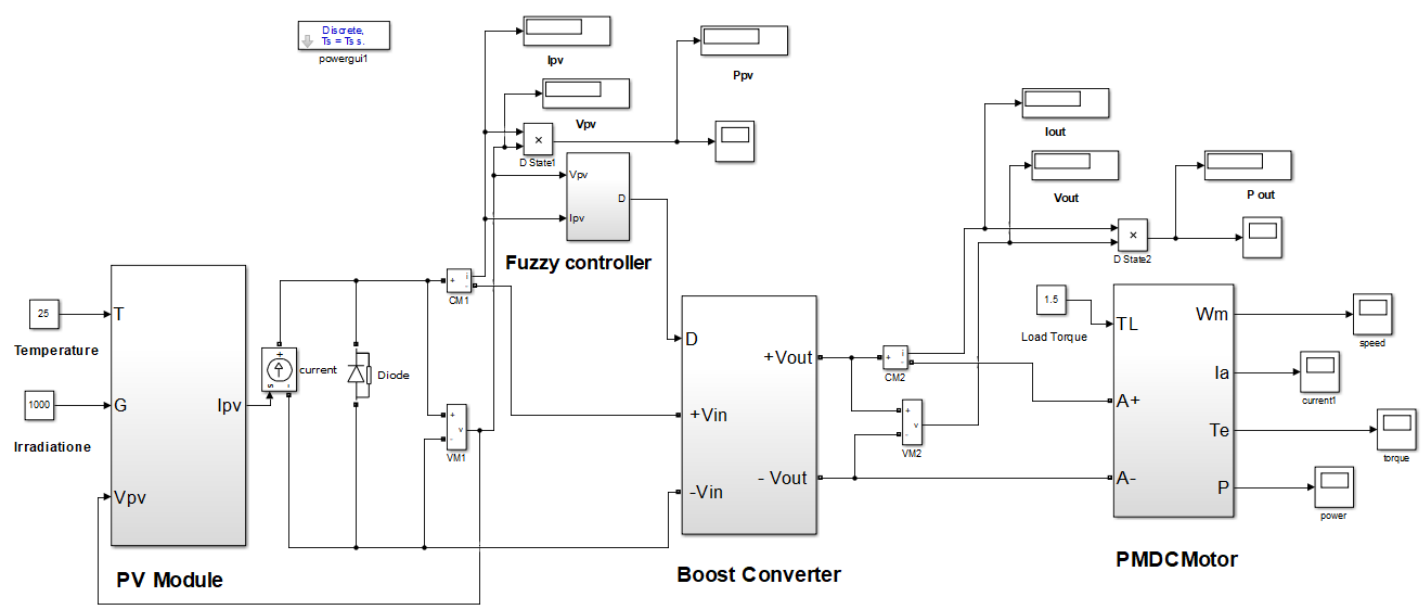

Fig.12: A simulation model of the PV system with an FLC controller.

\section{RESULTS AND DISCUSSION}

\subsection{Characteristics Of PV Module}

The PV module IS4000P 300 was selected to supply the PMDC motor coupled with the PD pump. Fig. 13 shows the simulated characteristics of the PV panel obtained using the developed model. THE PV MODULE'S characteristic P-V and I-V curves under different radiation levels and a constant temperature are given in Fig. 13 (a, b) for solar radiation values are $200,400,600,800$, and $1000 \mathrm{~W} / \mathrm{m}^{2}$ while temperature keeps constant at $25^{\circ} \mathrm{C}$. It can be observed that the output of the current and voltage rises as radiation increases. This leads to an increase in output power. The effect of temperature variation is shown in Fig. 13 (c, d). The temperature values are taken as $25,35,45,50$, and $55^{\circ} \mathrm{C}$, respectively, whereas the radiation level is constant at $1000 \mathrm{~W} / \mathrm{m}^{2}$. The output current increases slightly when the operating temperature rises, but the output voltage drops significantly. This results in an overall reduction of power output. 


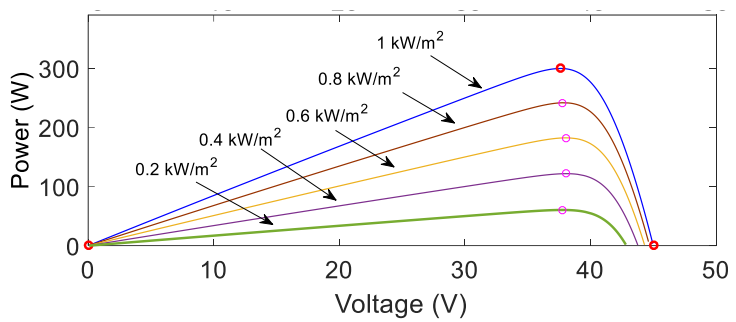

(b) Characteristic P-V curve of the PV panel under different radiation levels and a constant temperature $T=25^{\circ} \mathrm{C}$

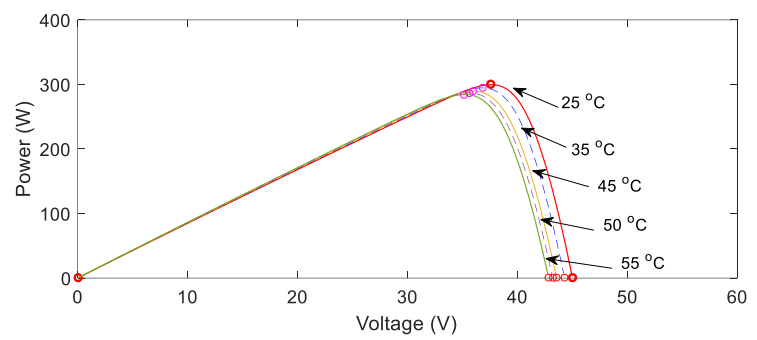

(c) Characteristic P-V curve of the PV panel under different operating temperatures and constant radiation of $1000 \mathrm{~W} / \mathrm{m}^{2}$

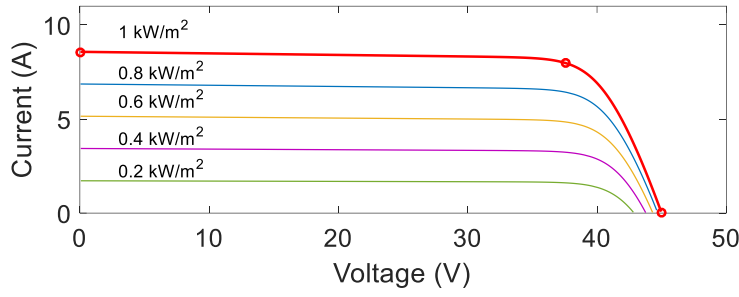

(a) Characteristic I-V curve of the PV panel under different radiation levels and a constant temperature $T=25^{\circ} \mathrm{C}$.

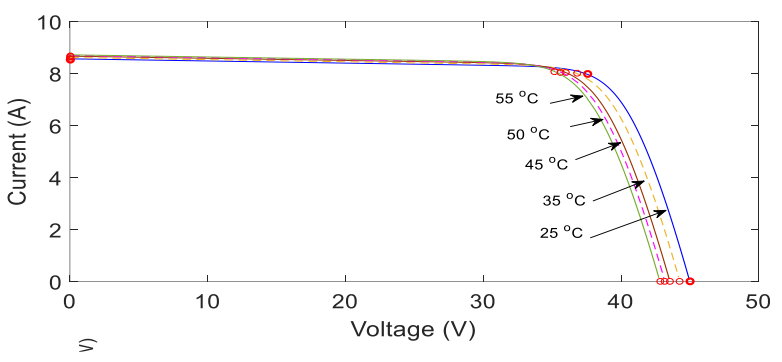

(d) Characteristic I-V curve of the PV panel under different operating temperatures and constant radiation of $1000 \mathrm{~W} / \mathrm{m}^{2}$

Fig.13: Characteristics of the PV panel.

\subsection{Applying MPPT}

The Matlab /Simulink model of PVPS was developed without MPPT (direct coupling) and with MPPT using FLC and a modified P\&O technique. The boost converter is an interface between a PV panel and a PMDC motor for impedance matching and transfer of maximum power between PV panel and motor. The proposed PVTWPS is simulated under different three cases: Case 1: Direct coupling without MPPT at STC as shown in Fig. 14.

Case 2: With MPPT using FLC and a modified P\&O at STC as shown in Fig. 15

Case 3: The radiation is fluctuating as step input while the temperature remains constant at $25^{\circ} \mathrm{C}$. The radiation begins at $1000 \mathrm{~W} / \mathrm{m}^{2}$ and remains for 0.4 seconds before dropping to 750 $\mathrm{W} / \mathrm{m}^{2}$. At $0.5 \mathrm{sec}$, the radiation increased to $900 \mathrm{~W} / \mathrm{m}^{2}$. At $0.6 \mathrm{sec}$, the radiation goes up to $1000 \mathrm{~W} / \mathrm{m}^{2}$, as shown in Fig. 16. In these conditions, the FLC technique could track the maximum generated power effectively. The $\mathrm{P} \& \mathrm{O}$ approach tracked maximum generated power, but oscillation around maximum power is bigger than that produced by the FLC technique.

The MPPT efficiency is calculated as shown in (13).

$\eta=\frac{P_{\mathrm{PV}}}{\mathrm{P}_{\mathrm{MPP}}}$

$P_{P V}$ is the power generated from the PV panel, and $P_{M P P}$ is the panel's maximum power. The efficiency of MPPT using the FLC technique is $99.77 \%$, and the efficiency of the P\&O method is $98.85 \%$ which is smaller than that obtained using the FLC MPPT method.

\subsection{Characteristics Of PVT Collector}

Simplified one-dimensional model was devolved and one geometry was designed to transfer the heat from the PV panel. The absorber is a direct flow circular tubes and sheet. A theoretical model was prepared for a water-type PVT collector using Matlab/Simulink platform. Validations for the present study were performed. The electrical and thermal performance of 
PVTWPS is determined under two levels of radiation $\left(\mathrm{G}=700 \mathrm{~W} / \mathrm{m}^{2}, 900 \mathrm{~W} / \mathrm{m}^{2}\right)$. At each solar radiation level various mass flow rates are introduced $(0.015,0.025,0.035,0.045 \mathrm{Kg} / \mathrm{s})$.

\subsubsection{Effect Of Mass Flow Rate On PVT Temperature And Outlet Temperature}

The thermal performance of the PVT water collector is determined under two levels of radiation. At each solar radiation level, various mass flow rates are introduced. The first condition at $\mathrm{G}=900 \mathrm{~W} / \mathrm{m}^{2}$ and $\mathrm{Ta}=40{ }^{\circ} \mathrm{C}$ and the second at $\mathrm{G}=700 \mathrm{~W} / \mathrm{m}^{2}$ and $\mathrm{Ta}=37{ }^{\circ} \mathrm{C}$. The results show that without active water cooling, the temperature of the PV panel reached $68{ }^{\circ} \mathrm{C}$ in the first condition. Variation of mass flow rate in the range of 0.015 to $0.045 \mathrm{Kg} / \mathrm{s}$ exhibited that the temperature of PVT decreased from $49.23{ }^{\circ} \mathrm{C}$ to $42.18^{\circ} \mathrm{C}$. The outlet temperature decreased from $57.2^{\circ} \mathrm{C}$ to $43.4{ }^{\circ} \mathrm{C}$, as shown in Fig.17. In the second condition, the temperature of the PV panel reached $57^{\circ} \mathrm{C}$. Variation of mass flow rate in the range of 0.015 to $0.045 \mathrm{Kg} / \mathrm{s}$. Results in decreasing the PVT temperature from $47.19^{\circ} \mathrm{C}$ to $42.54^{\circ} \mathrm{C}$. The outlet temperature decreased from $48.7^{\circ} \mathrm{C}$ to $41.6^{\circ} \mathrm{C}$, as shown in Fig.18.

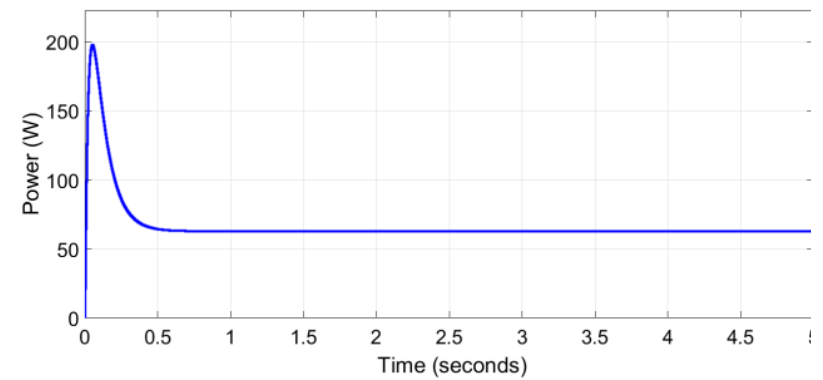

Fig.14: Output power versus time curve without MPPT at STC.

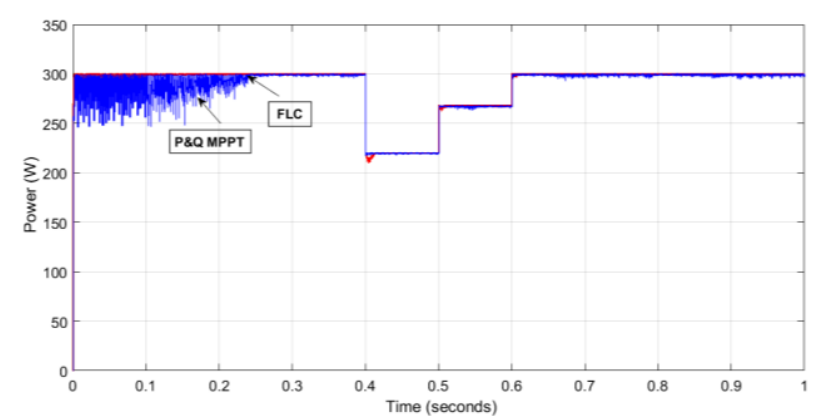

Fig.16: Output power of a modified $P \& O$ technique and the FLC under different radiation levels and constant temperature $25^{\circ} \mathrm{C}$.

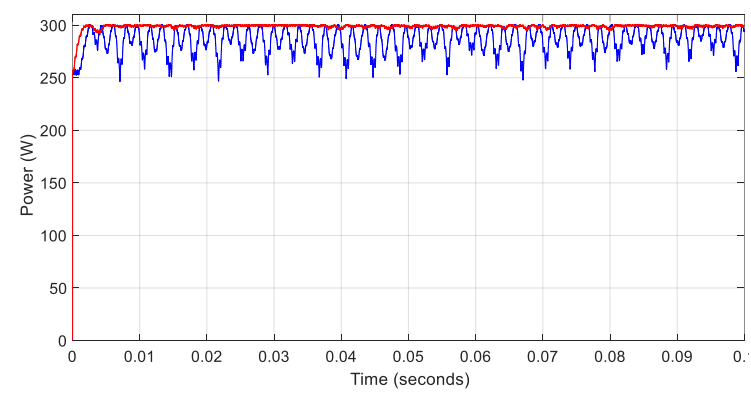

Fig.15: Output power of a modified P\&O technique and the FLC at STC.

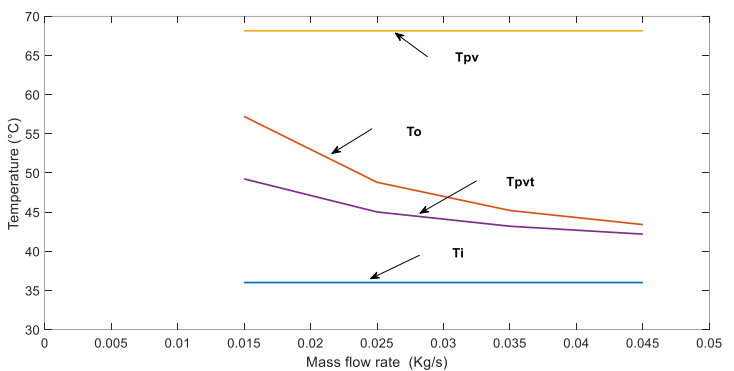

Fig. 17: Variation of PVT collector and output temperatures with various mass flow rates at $\mathrm{G}$ $=900 \mathrm{~W} / \mathrm{m}^{2}$ and $\mathrm{Ta}=40^{\circ} \mathrm{C}$.

\subsubsection{Effect Of Mass Flow Rate On PV and PVT Maximum Output Power}

The electrical performance of PV and PVT water collectors is determined. The first condition shows that PVT's maximum output power increased from 214 to 228 watts by increasing the mass flow rate as compared to the maximum output power of PV 173.9 watt, as shown in Fig.19. In the second condition, the maximum output power of PVT increased from 166.4 to 174 watts as compared to the maximum output power of PV 148.2 watts, as shown in Fig.20. 


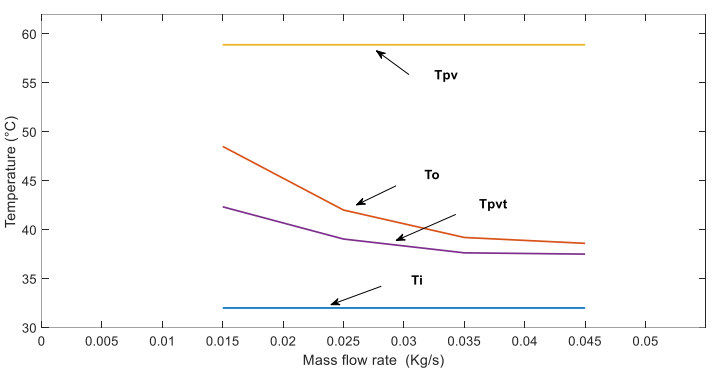

Fig. 18: Figure 14: Variation of PVT collector and output temperatures with various mass flow rates at $\mathrm{G}=700 \mathrm{~W} / \mathrm{m}^{2}$ and $\mathrm{Ta}=37^{\circ} \mathrm{C}$

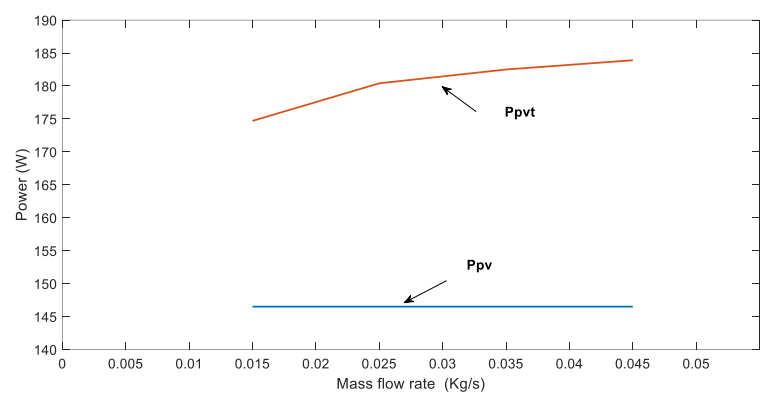

Fig.20: presents the effect of mass flow rate on the maximum output power of PV and PVT at $\mathrm{G}=700 \mathrm{~W} / \mathrm{m}^{2}$ and $\mathrm{Ta}=37{ }^{\circ} \mathrm{C}$

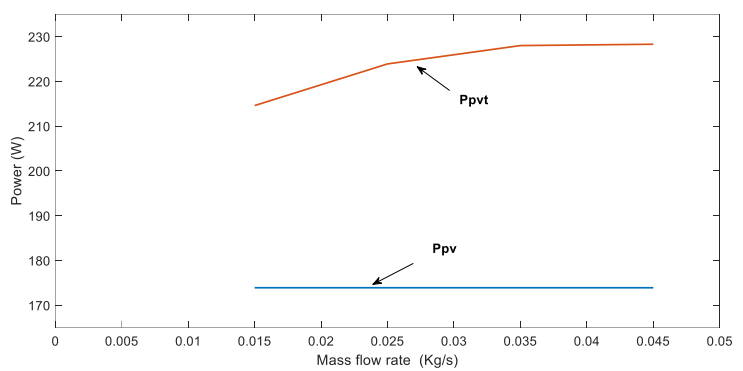

Fig.19: The mass flow rate's effect on the maximum output power of PV and PVT at G $=900 \mathrm{~W} / \mathrm{m}^{2}$ and $\mathrm{Ta}=40{ }^{\circ} \mathrm{C}$.

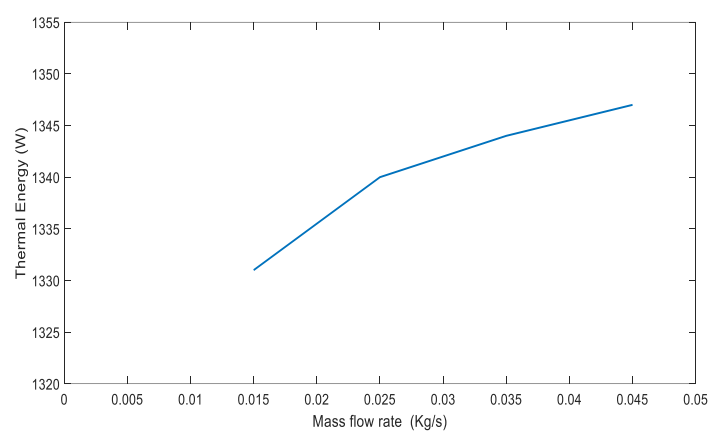

Fig.21: The mass flow rate's effect on the thermal energy obtained from PVT at $\mathrm{G}=900 \mathrm{~W} / \mathrm{m}^{2}$ and $\mathrm{Ta}=40^{\circ} \mathrm{C}$.

\subsubsection{Effect Of Mass Flow Rate On The Thermal Energy For PVT Collector}

The thermal performance of the PVT water collector is determined. The results show that in the first condition, the thermal energy of PVT increased from 1331 to 1347 watts by increasing mass flow rate, as shown in Fig.21. In the second condition, the thermal energy of PVT rose from 859.7 to 861.5 watts, as shown in Fig.22.

\subsubsection{Effect Of Mass Flow Rate On The Electrical, Thermal And Overall Efficiency For PV And PVT}

The electrical efficiency of the PVT water collector is calculated .(see eq.18 ). Results show that by increasing mass flow rate PVT, electrical efficiency increased from $13.25 \%$ to $14.09 \%$ compared to PV electrical efficiency ( without cooling) $=10.73 \%$ in the first condition, as shown in Fig.23.In the second condition, the PVT electrical efficiency increased from $13.95 \%$ to $14.33 \%$ than PV electrical efficiency ( without cooling) $=11.76 \%$, as shown in Fig.23. The thermal efficiency of the PVT water collector is calculated. (see eq.19). Results show that by increasing mass flow rate PVT, thermal efficiency increased from $82.18 \%$ to 83.13\% in the first condition, as shown in Fig.24. The PVT thermal efficiency increased from $68.19 \%$ to $68.35 \%$ in the second condition, as shown in Fig.24. The overall efficiency of the PVT water collector is calculated. (see eq.17). Results show that increasing mass flow rate PVT's overall efficiency increased from $95.43 \%$ to $97.22 \%$ in the first condition, as shown in 
Fig.25. In the second condition, the PVT thermal efficiency increased from $96.27 \%$ to 97.9 \%, as shown in Fig.25.

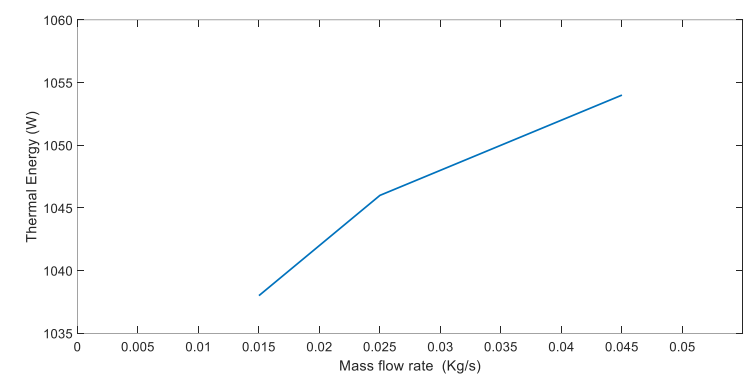

Fig.22: presents the effect of mass flow rate on the thermal energy obtained from PVT $\mathrm{G}=700$ $\mathrm{W} / \mathrm{m}^{2}$ and $=37^{\circ} \mathrm{C}$.

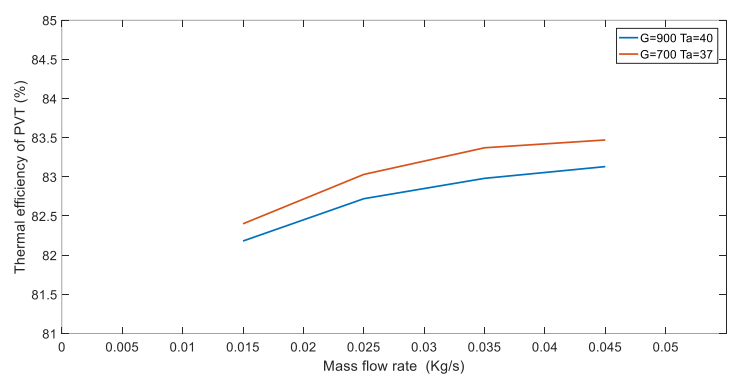

Fig.24: presents the effect of mass flow rate on the thermal efficiency of PVT collectors.

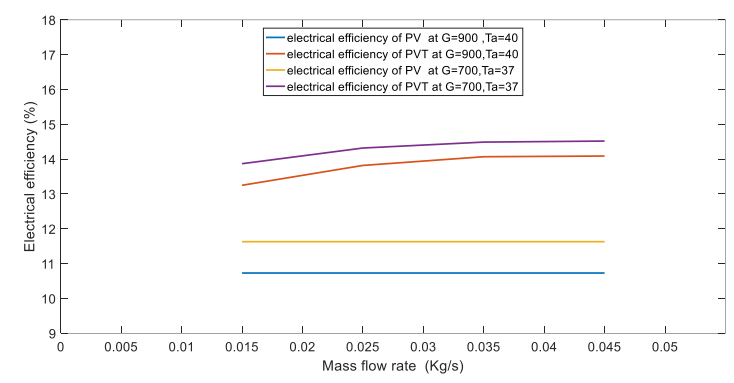

Fig.23: presents the effect of mass flow rate on the electrical efficiency of the PVT collector.

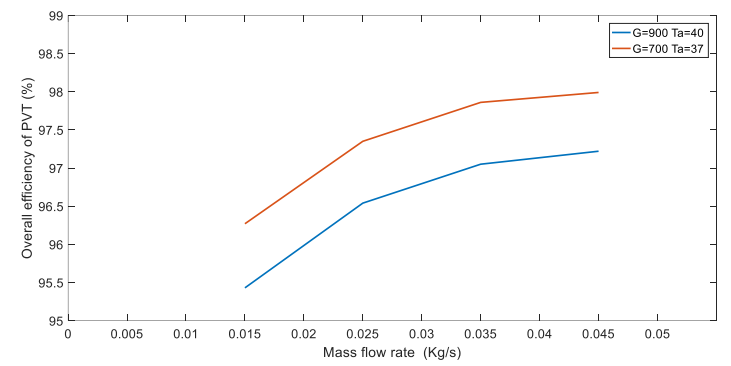

Fig.25: presents the effect of mass flow rate on the Overall efficiency of PVT collector.

\section{CONCLUSION}

Overheating caused by excessive radiation and high temperature is one of the most significant challenges facing PV operations. For cooling PV, a mathematical model was constructed to evaluate the performance of a PVT collector in generating thermal and electrical energy. The proposed mathematical model's reliability was validated by comparing the current study to previously published data in the literature. Simulation results show that at $\mathrm{G}=900 \mathrm{~W} / \mathrm{m} 2$ and $\mathrm{Ta}=40^{\circ} \mathrm{C}$. The electrical efficiency of the PVT collector increased by $31.2 \%$ compared to PV module efficiency. Thermal efficiency of the PVT collector reached $83.13 \%$, and overall efficiency was $97.22 \%$. A control system is designed to track the maximum power produced from the PVT collector, supplying DC motor pump load. Simulation results show that the FLC accurately tracks the MPP under various ambient conditions. The oscillation around MPP is diminished, and the response is faster compared with the modified $\mathrm{P} \& \mathrm{O}$ technique. When the tracking efficiency of both methods is compared, the FLC exceeds the modified P\&O technique.

\section{REFERENCES :}

1. Tripanagnostopoulos, Y., Souliotis, M., Battisti, R., \& Corrado, A. (2005). Energy, cost and LCA results of PV and hybrid PV/T solar systems. Progress in Photovoltaics: Research and applications, 13(3), 235-250.

2. El-Khatib, M. F., Shaaban, S., \& El-Sebah, M. I. A. (2017). A proposed advanced maximum power point tracking control for a photovoltaic-solar pump system. Solar Energy, 158, 321-331. 


\section{MODELING OF HYBRID PHOTOVOLTAIC THERMAL WATER PUMPING SYSTEM}

3. Hossain, M. S., Pandey, A. K., Selvaraj, J., Abd Rahim, N., Islam, M. M., \& Tyagi, V. V. (2019). Two side serpentine flow based photovoltaic-thermal-phase change materials (PVT-PCM) system: Energy, exergy and economic analysis. Renewable Energy, 136, 1320-1336.

4. Hamid, S. A., Othman, M. Y., Sopian, K., \& Zaidi, S. H. (2014). An overview of photovoltaic thermal combination (PV/T combi) technology. Renewable and Sustainable Energy Reviews, 38, 212-222.

5. Kern Jr, E. C., \& Russell, M. C. (1978). Combined photovoltaic and thermal hybrid collector systems (No. COO-4577-3; CONF-780619-24). Massachusetts Inst. of Tech., Lexington (USA). Lincoln Lab

6. Florschuetz, L. W. (1979). Extension of the Hottel-Whillier model to the analysis of combined photovoltaic/thermal flat plate collectors. Solar energy, 22(4), 361-366.

7. Fudholi, A., Sopian, K., Yazdi, M. H., Ruslan, M. H., Ibrahim, A., \& Kazem, H. A. (2014). Performance analysis of photovoltaic thermal (PVT) water collectors. Energy conversion and management, 78, 641-651.

8. Al-Shamani, A. N., Sopian, K., Mat, S., Hasan, H. A., Abed, A. M., \& Ruslan, M. H. (2016). Experimental studies of rectangular tube absorber photovoltaic thermal collector with various types of nanofluids under the tropical climate conditions. Energy Conversion and Management, 124, 528542.

9. Yu, Y., Long, E., Chen, X., \& Yang, H. (2019). Testing and modelling an unglazed photovoltaic thermal collector for application in Sichuan Basin. Applied Energy, 242, 931-941.

10. Rosen, M. A., \& Kumar, R. (2011). Performance of a photovoltaic/thermal solar air heater: effect of vertical fins on a double pass system.

11. Kazemian, A., Salari, A., Hakkaki-Fard, A., \& Ma, T. (2019). Numerical investigation and parametric analysis of a photovoltaic thermal system integrated with phase change material. Applied energy, 238, 734-746

12. Fayaz, H., Rahim, N. A., Hasanuzzaman, M., Rivai, A., \& Nasrin, R. (2019). Numerical and outdoor real time experimental investigation of performance of PCM based PVT system. Solar Energy, 179, 135-150.

13. Gaur, A., Ménézo, C., \& Giroux, S. (2017). Numerical studies on thermal and electrical performance of a fully wetted absorber PVT collector with PCM as a storage medium. Renewable Energy, 109, 168-187.

14. AL-Musawi, A. I. A., Taheri, A., Farzanehnia, A., Sardarabadi, M., \& Passandideh-Fard, M. (2019). Numerical study of the effects of nanofluids and phase-change materials in photovoltaic thermal (PVT) systems. Journal of Thermal Analysis and Calorimetry, 137(2), 623-636.

15. Al-Waeli, A. H., Kazem, H. A., Chaichan, M. T., \& Sopian, K. (2019). Experimental investigation of using nano-PCM/nanofluid on a photovoltaic thermal system (PVT): technical and economic study. Thermal Science and Engineering Progress, 11, 213-230.

16. Hossain, M. S., Pandey, A. K., Selvaraj, J., Abd Rahim, N., Islam, M. M., \& Tyagi, V. V. (2019). Two side serpentine flow based photovoltaic-thermal-phase change materials (PVT-PCM) system: Energy, exergy and economic analysis. Renewable Energy, 136, 1320-1336.

17. Ramos, A., Chatzopoulou, M. A., Guarracino, I., Freeman, J., \& Markides, C. N. (2017). Hybrid photovoltaic-thermal solar systems for combined heating, cooling and power provision in the urban environment. Energy conversion and management, 150, 838-850.

18. Herrando, M., Pantaleo, A. M., Wang, K., \& Markides, C. N. (2019). Solar combined cooling, heating and power systems based on hybrid PVT, PV or solar-thermal collectors for building applications. Renewable Energy, 143, 637-647. 


\section{MODELING OF HYBRID PHOTOVOLTAIC THERMAL WATER PUMPING SYSTEM}

19. El-Shafy A. Nafeh, A., Fahmy, F. H., \& Abou El-Zahab, E. M. (2002). Maximum-power operation of a standalone PV system using fuzzy logic control. International Journal of Numerical Modelling: Electronic Networks, Devices and Fields, 15(4), 385-398.

20. Bhattacharyya, S., Samanta, S., \& Mishra, S. (2020). Steady Output and Fast Tracking MPPT (SOFT-MPPT) for P\&O and InC Algorithms. IEEE Transactions on Sustainable Energy, 12(1), 293 302.

21. Garud, K. S., Jayaraj, S., \& Lee, M. Y. (2021). A review on modeling of solar photovoltaic systems using artificial neural networks, fuzzy logic, genetic algorithm and hybrid models. International Journal of Energy Research, 45(1), 6-35.

22. Yang, B., Zhu, T., Wang, J., Shu, H., Yu, T., Zhang, X., ... \& Sun, L. (2020). Comprehensive overview of maximum power point tracking algorithms of PV systems under partial shading condition. Journal of Cleaner Production, 268, 121983.

23. Oi, A. (2005). Design and simulation of photovoltaic water pumping system. California Polytechnic State University.

24. Rawat, R., Kaushik, S. C., \& Lamba, R. (2016). A review on modeling, design methodology and size optimization of photovoltaic based water pumping, standalone and grid connected system. Renewable and Sustainable Energy Reviews, 57, 1506-1519.

25. Katan, R. E., Agelidis, V. G., \& Nayar, C. V. (1996, January). Performance analysis of a solar water pumping system. In Proceedings of International Conference on Power Electronics, Drives and Energy Systems for Industrial Growth (Vol. 1, pp. 81-87). IEEE.

26. Khan, S. I., Sarkar, M. M. R., \& Islam, M. Q. (2013). Design and analysis of a low cost solar water pump for irrigation in Bangladesh. Journal of Mechanical Engineering, 43(2), 98-102.

27. García, A. M., Gallagher, J., McNabola, A., Poyato, E. C., Barrios, P. M., \& Díaz, J. R. (2019). Comparing the environmental and economic impacts of on-or off-grid solar photovoltaics with traditional energy sources for rural irrigation systems. Renewable Energy, 140, 895-904.

28. Michael, J. J., Iniyan, S., \& Goic, R. (2015). Flat plate solar photovoltaic-thermal (PV/T) systems: a reference guide. Renewable and sustainable energy reviews, 51, 62-88.

29. Villalva, M. G., Gazoli, J. R., \& Ruppert Filho, E. (2009). Comprehensive approach to modeling and simulation of photovoltaic arrays. IEEE Transactions on power electronics, 24(5), 1198-1208.

30. Tsai, H. L., Tu, C. S., \& Su, Y. J. (2008, October). Development of generalized photovoltaic model using MATLAB/SIMULINK. In Proceedings of the world congress on Engineering and computer science (Vol. 2008, pp. 1-6).

31. Altas, I. H., \& Sharaf, A. M. (2007, May). A photovoltaic array simulation model for MatlabSimulink GUI environment. In 2007 International Conference on Clean Electrical Power (pp. 341345). IEEE.

32. Solanki, C. S. (2015). Solar photovoltaics: fundamentals, technologies and applications. Phi learning pvt. Ltd..

33. Zahab, E. E. A., Zaki, A. M., \& El-sotouhy, M. M. (2017). Design and control of a standalone PV water pumping system. Journal of Electrical Systems and Information Technology, 4(2), 322-337.

34. Ahmed, F. I., Mahfouz, A. A., \& Ibrahim, M. M. (1999). A novel fuzzy controller for DC motor drives.

35. Hissouf, M., Najim, M., \& Charef, A. (2020). Performance of a photovoltaic-thermal solar collector using two types of working fluids at different fluid channels geometry. Renewable Energy, 162, 1723-1734. 


\section{MODELING OF HYBRID PHOTOVOLTAIC THERMAL WATER PUMPING SYSTEM}

36. Zhang, X., Zhao, X., Smith, S., Xu, J., \& Yu, X. (2012). Review of R\&D progress and practical application of the solar photovoltaic/thermal (PV/T) technologies. Renewable and Sustainable Energy Reviews, 16(1), 599-617.

37. Hottel, H., \& Whillier, A. (1955, January). Evaluation of flat-plate solar collector performance. In Trans. Conf. Use of Solar Energy;() (Vol. 3).

38. Vokas, G., Christandonis, N., \& Skittides, F. (2006). Hybrid photovoltaic-thermal systems for domestic heating and cooling - a theoretical approach. Solar energy, 80(5), 607-615.

39. DW, J., \& WWS C, P. (1977). Solar and wind induced external coefficients for solar collectors. Coop Mediterr Pour l'Energie Solaire. Rev Int d'Heliotechnique, 2, 56.

40. Sun, V., Asanakham, A., Deethayat, T., \& Kiatsiriroat, T. (2020). A new method for evaluating nominal operating cell temperature (NOCT) of unglazed photovoltaic thermal module. Energy Reports, 6, 1029-1042.

41. Ross Jr, R. G. (1980). Flat-plate photovoltaic array design optimization. In 14th Photovoltaic Specialists Conference (pp. 1126-1132).

42. Abdullah, A. L., Misha, S., Tamaldin, N., Rosli, M. A. M., \& Sachit, F. A. (2020). Theoretical study and indoor experimental validation of performance of the new photovoltaic thermal solar collector (PVT) based water system. Case Studies in Thermal Engineering, 18, 100595.

43. Rashid, M. H. (2009). Power electronics: circuits, devices, and applications. Pearson Education India.

44. Farahat, M. A., Metwally, H. M. B., \& Mohamed, A. A. E. (2012). Optimal choice and design of different topologies of DC-DC converter used in PV systems, at different climatic conditions in Egypt. Renewable Energy, 43, 393-402.

45. Beriber, D., \& Talha, A. (2013, May). MPPT techniques for PV systems. In 4th International Conference on Power Engineering, Energy and Electrical Drives (pp. 1437-1442). IEEE. 